\title{
Spatio-temporal mosaic of the phytoplankton spring bloom in the open Baltic Sea in 1986
}

\author{
Mati Kahru ${ }^{1}$, Juha-Markku Leppänen ${ }^{2}$, Sulev Nômmann ${ }^{1}$, Uta Passow ${ }^{3}$, Lutz Postel ${ }^{4}$, \\ Sigurd Schulz ${ }^{4}$
}

${ }^{1}$ Institute of Ecology and Marine Research, Paldiski Rd 1, 200031 Tallinn, Estonia, USSR

${ }^{2}$ Finnish Institute of Marine Research, PO Box 33, SF-00931 Helsinki, Finland

${ }^{3}$ Institut für Meereskunde an der Universität Kiel, Düsternbrooker Weg 20, D-2300 Kiel, Federal Republic of Germany

${ }^{4}$ Institut für Meereskunde, Seestr. 15, 2530 Rostock-Warnemünde, German Democratic Republic

\begin{abstract}
The spatio-temporal variability of the phytoplankton spring bloom in the open Baltic Sea during an international joint study (PEX 86) is described in relation to the physical and chemical environment. Simultaneous participation of 14 research vessels enabled highly synoptic sampling of the study area of $20 \times 40 \mathrm{n}$ mile. Onset of the bloom was controlled by mesoscale hydrodynamic features $-\mathrm{a}$ pair of cyclonic and anticyclonic eddies; water masses with different salinities. The eddies supported an exceptionally high amount of chlorophyll (>700 $\mathrm{mg} \mathrm{m}^{-2}$ in the cyclonic eddy). The temporal development of the bloom was different in each of the mesoscale features. Chlorophyll levels in the eddies started to decrease due to sedimentation before formation of the thermocline and the depletion of inorganic nutrients. Variability of the chlorophyll distribution was highest just before the peak in the spatially averaged concentration was attained.
\end{abstract}

\section{INTRODUCTION}

Satellite images of the sea-surface temperature and pigment distributions (Horstmann 1983, Horstmann et al. 1986) suggest that the Baltic Sea consists of a mosaic of tightly packed eddy-like features. They have also given new support to the widespread notion held by biological oceanographers of patchy distribution of plankton and other organisms. The patchy, or in statistical terms 'overdispersed' distribution patterns of plankton organisms are believed to have a great impact on trophic relationships and competition in plankton communities (Steele 1978). Due to the complexity of and the close coupling between many environmental and biological processes, the implications of such patchy distributions are still little understood.

In a study of chlorophyll patchiness in the open Baltic Sea, Kahru et al. (1982) showed that the highest variability in phytoplankton biomass occurs during the spring bloom period. To explain this drastic variability, they conjectured that at least part of the mesoscale spatial variability was caused by differences in the time when the bloom commenced. Observations by Bodungen et al. (1981) and Kahru \& Nômmann (1990) have shown that, contrary to the common understanding (e.g. Kaiser \& Schulz 1978, Hällfors \& Niemi 1981), the phytoplankton spring bloom in the Baltic Sea may start before thermocline formation. As outlined by Kahru \& Nômmann (1990), the vertical stability necessary for the onset of the spring bloom can be provided by the slight vertical stratification of salinity which reduces the mixed layer depth. Thus stability in the open sea could be generated locally by synoptic-scale eddies and filaments.

The Patchiness Experiment (PEX'86), an international joint study, was aimed at investigating patchiness on spatial scales of 2 to $40 \mathrm{n}$ mile, and on temporal scales varying from days to a few weeks during the spring bloom in the central Baltic Sea (Dybern \& Hansen 1989). Simultaneous participation of 14 research vessels adjoining most of the countries around the Baltic Sea permitted highly synoptic sampling of the study area. This paper describes the spatio-temporal variability of the phytoplankton spring bloom in terms of chlorophyll concentration in relation to the hydrographic structures in the open Baltic Sea during April and May 1986.

\section{MATERIAL AND METHODS}

The sampling period extended from 25 April to 7 May 1986. The sampling area was situated in the Eastern Gotland basin of the Baltic Proper (Fig. 1). The 

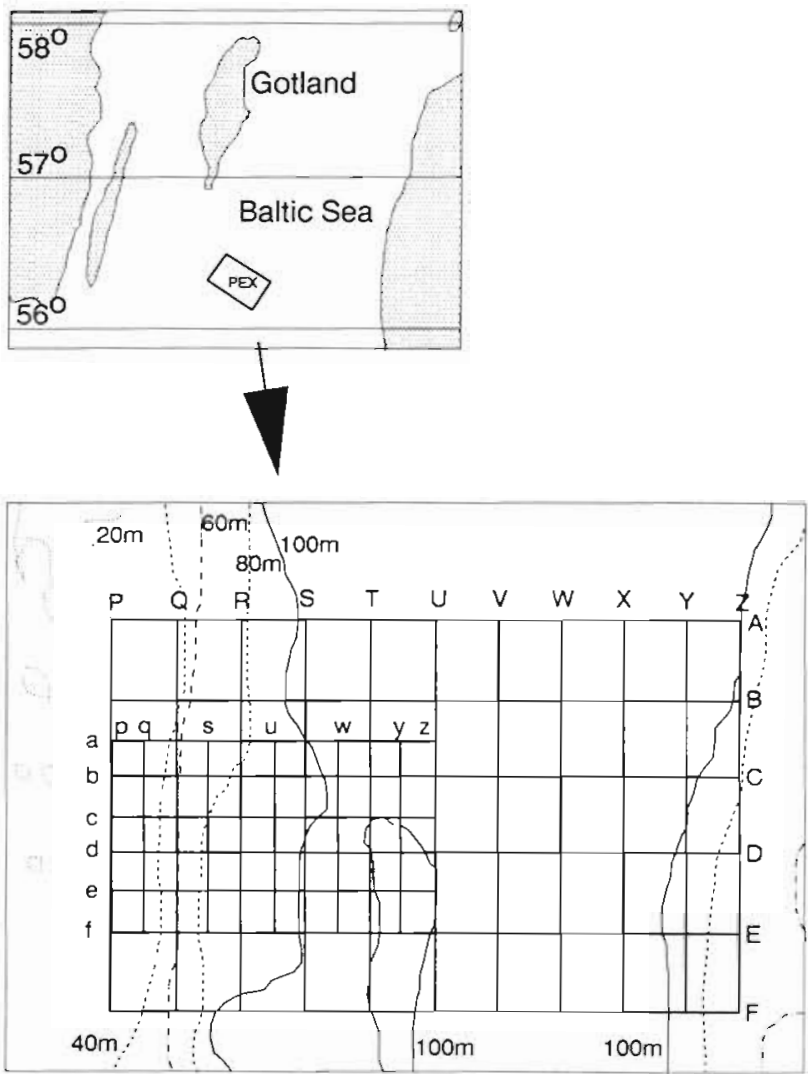

Fig. 1. The Central Baltic Proper showing the study area. The large box of $20 \times 40 \mathrm{n}$ mile represents the Eddy grid area and the smaller one of $10 \times 20 \mathrm{n}$ mile is the Slope grid area

ships sampled synchronously at stations along 6 parallel lines on 2 grids of stations (Fig. 1) moving from west to east. In the larger 'Eddy grid' $(20 \times 40 \mathrm{n}$ mile) the distance between stations was $4 \mathrm{n}$ mile, whereas in the smaller 'Slope grid' $(10 \times 20 \mathrm{n}$ mile) stations were $2 \mathrm{n}$ mile apart. The time interval between consecutive stations was $1.5 \mathrm{~h}$ in both cases. Chlorophyll a was sampled at every station, and primary production at every second station. Sampling depths for primary production were $1,5,10$, and $20 \mathrm{~m}$; for chlorophyll a additionally $30 \mathrm{~m}$.

The methods described by Helcom (1983) were used in sampling and analyses. Intercalibration of the chlorophyll $a$ and primary production measurements indicated that there were statistically significant differences between the results from the individual ships (Leppänen et al, unpubl.). However, the natural variation encountered during the field experiment was clearly higher. The $95 \%$ confidence limits for the means of all ships were ca $\pm 0.5 \mathrm{mg} \mathrm{m} \mathrm{m}^{-3}$ for chlorophyll a. The corresponding value for primary production capacity was $\pm 3 \mathrm{mg} \mathrm{C} \mathrm{m} \mathrm{m}^{-3} \mathrm{~h}^{-1}$ when the production level was high in the beginning of the study period, and later on $\pm 0.5 \mathrm{mg} \mathrm{C} \mathrm{m}^{-3} \mathrm{~h}^{-1}$. The bias due

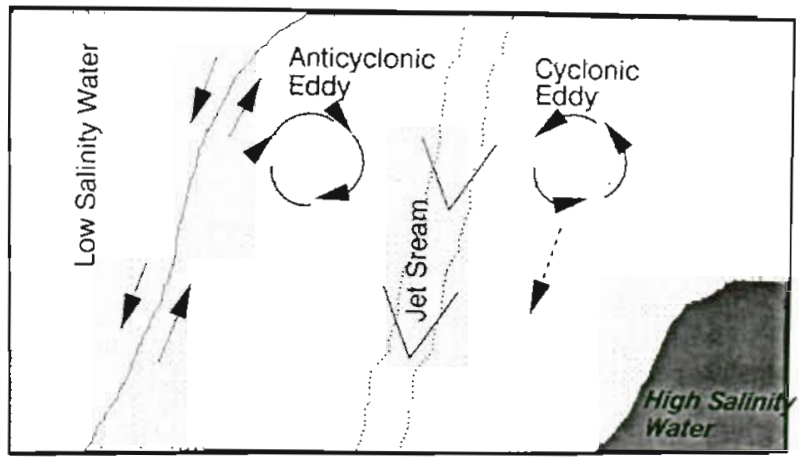

Fig. 2. Schematic representation of the different water masses in the study area (redrawn from the scheme by J. Elken in Dybern \& Hansen 1989)

to the diurnal rhythm in the primary production capacity may have an effect on the spatial patterns.

Continuous measurements of chlorophyll a fluorescence made by one ship on horizontal tracks along Line $\mathrm{C}$ (Turner Designs flow-through fluorometer) were used to check the spatial aliasing problem. Sampling depth on the tracks was $5 \mathrm{~m}$ and spatial resolution 200 to $300 \mathrm{~m}$. Vertical profiles of chlorophyll in situ fluorescence were measured by submersible fluorometer (Electro-Optik Suarez) to estimate in detail the water column chlorophyll down to a depth of 60 to $70 \mathrm{~m}$.

Horizontal patchiness was described by selecting the layer of 0 to $10 \mathrm{~m}$ to represent the euphotic layer. Vertical variation in chlorophyll a concentrations was small in this layer, and the mean values therefore give the same pattern as using single depth values. Vertical averaging, however, increases the reliability of the contour maps by reducing the effect of methodological noise.

\section{METEOROLOGICAL AND HYDROGRAPHICAL BACKGROUND}

The daily totals of solar radiation $(12000$ to $20000 \mathrm{~kJ}$ $\mathrm{m}^{-2}$ ) were above the long-term average in the open Baltic for the last third of April and first third of May (Dybern \& Hansen 1989). Owing to the relatively calm weather during the whole PEX'86 period, windinduced mixing in the surface layers was probably below the long-term average.

The 4 hydrographical Eddy grid surveys showed the existence of a relatively persistent pattern of separate water masses and mesoscale features: low-salinity $(<7.5 \%$ ) water on the shallow western bank, a highsalinity $(>7.64 \%$ ) tongue in the southeastern comer, and a pair of synoptic scale eddies in the intermediatesalinity water in the middle (Fig. 2). The relative persistence of these synoptic scale features was also sup- 
Fig. 3. Variability of chlorophyll a concentrations $\left(\mathrm{mg} \mathrm{m}^{-3}\right)$ in the 0 to $10 \mathrm{~m}$ layer in the whole study area. Eddy grids are indicated by arrows. Central box covers the middle $50 \%$ of the data values, between the upper and lower quartiles; central line is the median; 'whiskers' extend to the upper/lower quartile $\pm 3 \times$ interquartile range. Extreme values are plotted as separate asterisks ("). Average number of observations is 198 for each grid

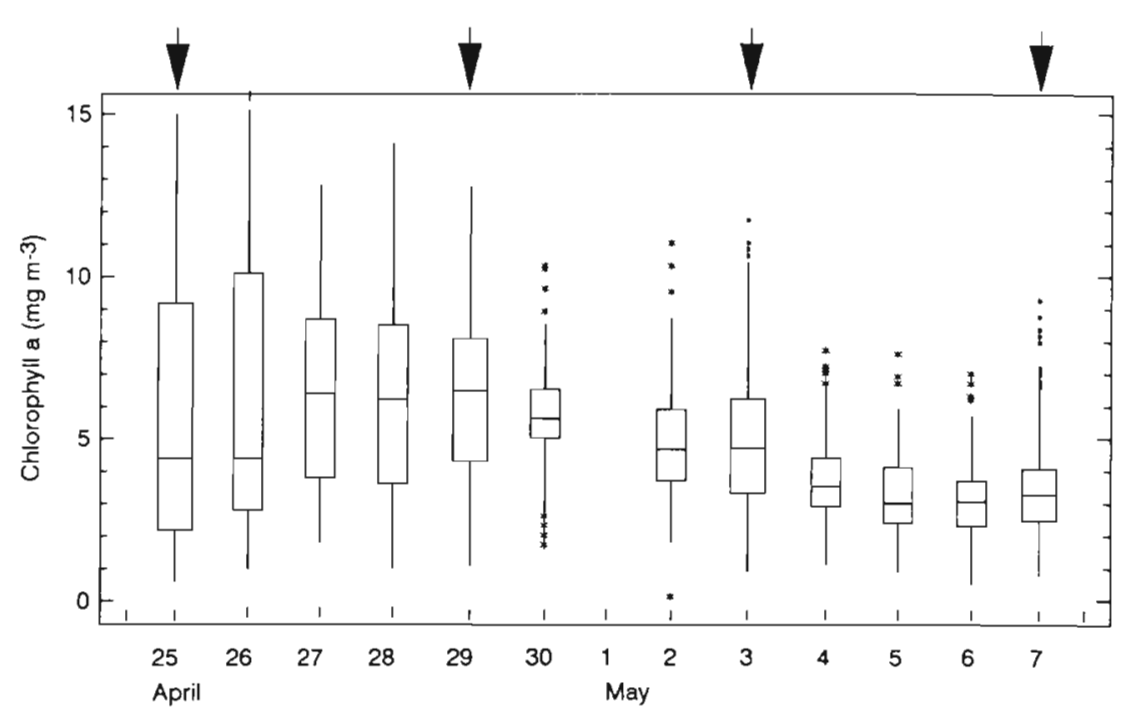

ported by the current measurements (Dybern \& Hansen 1989). The low-salinity water was bounded on the east by a quasi-stationary front described by Elken et al. (1987), and was characterized by very low current speeds (Dybern \& Hansen 1989). The 2 eddies were separated by a southward directed jet-like current, and seemed to form a vortex pair consisting of a cyclonic and an anticyclonic eddy (Fig. 2). The high-salinity water tongue seemed to protrude and broaden slowly northward, part of it being separated during the last surveys. The cyclonic eddy was persistent throughout the whole study period, moving slowly southwards. In contrast, the anticyclonic eddy disintegrated before the formation of the thermocline.

\section{RESULTS}

The investigation period covered the end of the increasing phase, the peak, and the declining phase of the phytoplankton spring bloom, as shown by observations before and after the main PEX period (Kahru \& Nommann 1990). Daily sedimentation rates of the dominant phytoplankton species were very high during the declining phase of the bloom (Passow 1990) whereas zooplankton biomass was low throughout the investigation period (Dybern \& Hansen 1989), indicating negligible grazing pressure. While the median chlorophyll concentration over the PEX area increased until 27 April, and then subsequently decreased, the spatial variance showed a general decline from very high variability on 25 to 26 April towards the end of the bloom (Fig. 3).

Due to the inherent plankton variability on scales below the 4 -mile and 2-mile resolution of the Eddy and Slope grids, respectively, the distribution patterns given by these surveys may be significantly biased (Fig. 4). The biasing effect was strongest for the period after 1 May, when together with the formation of the seasonal thermocline the smaller-scale variability component increased considerably. However, the surveys on the grids identified the main structures.

The synoptic scale hydrography patterns show a clear correspondence with the distribution and development patterns of the chlorophyll and primary
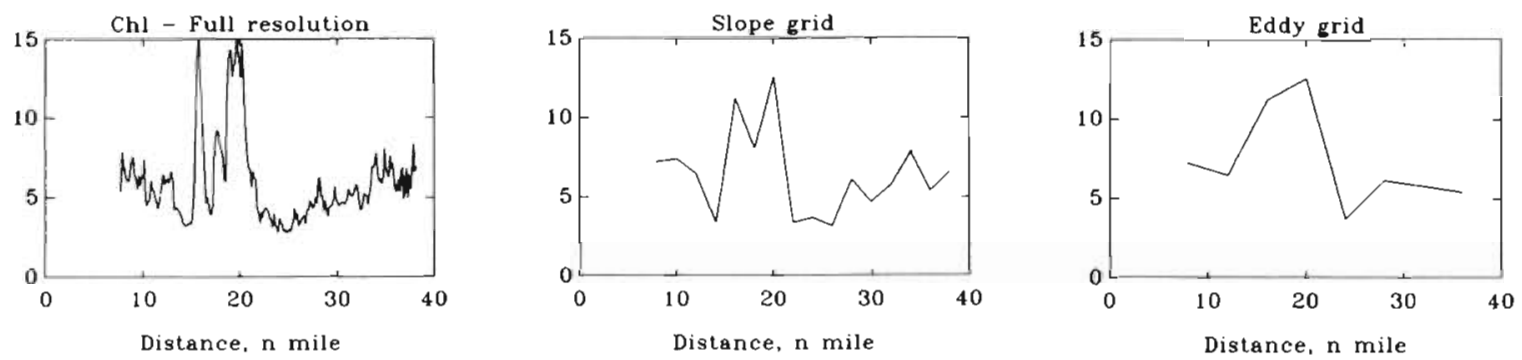

Fig. 4. Horizontal transect of chlorophyll a $\left(\mathrm{mg} \mathrm{m}^{-3}\right)$ as calculated from fluorescence along Line $\mathrm{C}$ of the Eddy grid on $3 \mathrm{May} 1986$ with a full resolution of about $250 \mathrm{~m}$, and the patterns resulting from picking the values corresponding to the 2 mile step of the Slope grid and the 4 mile step of the Eddy grid from the same series 

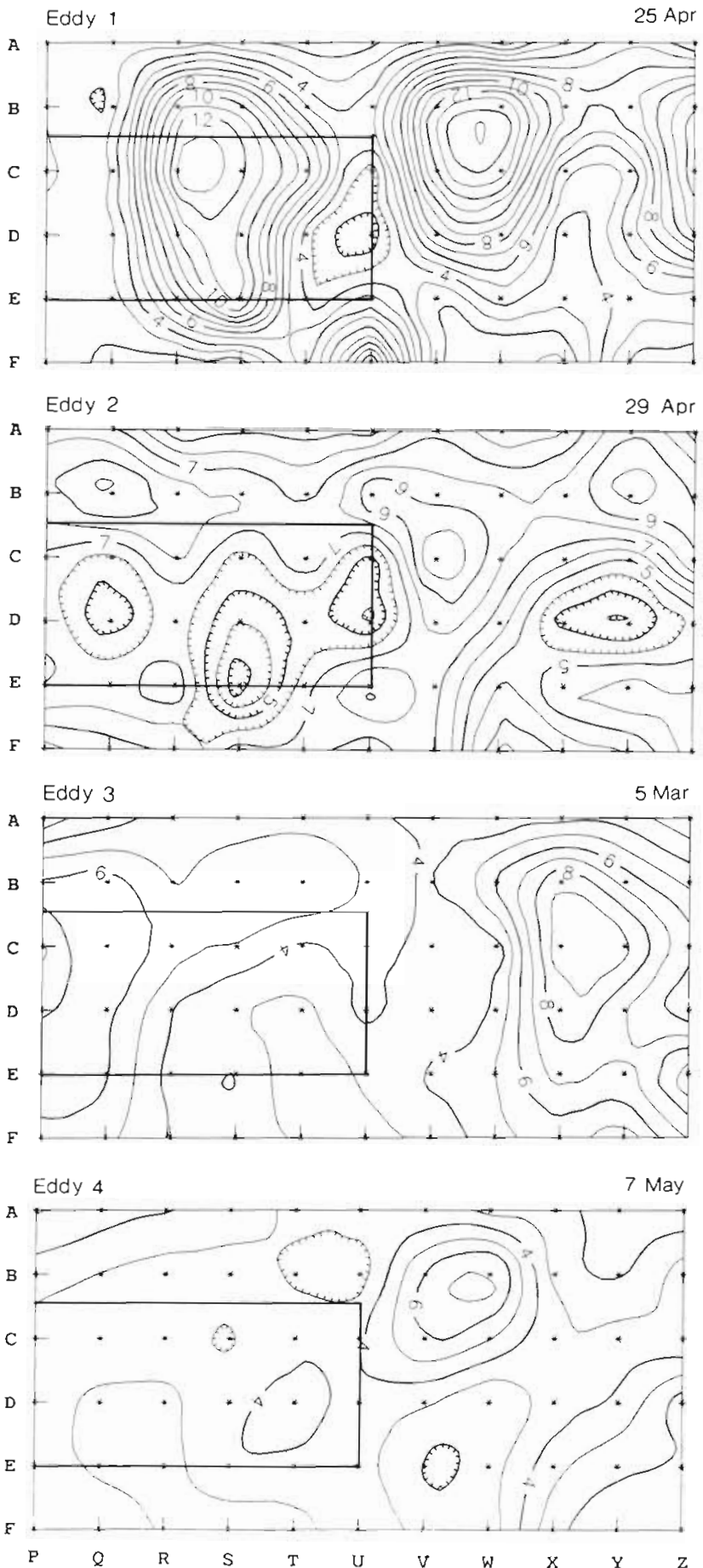

Fig. 5. Contour maps of the horizontal chlorophyll a distribution $\left(\mathrm{mg} \mathrm{m}^{-3}\right)$ in the 0 to $10 \mathrm{~m}$ water layer in the Eddy grids

production in the upper layer (Figs. 5 to 7). Coupling between the hydrographic distributions and the plankton distributions was especially close during the increasing and peak phases of the bloom, and decreased later due to sedimentation of phytoplankton
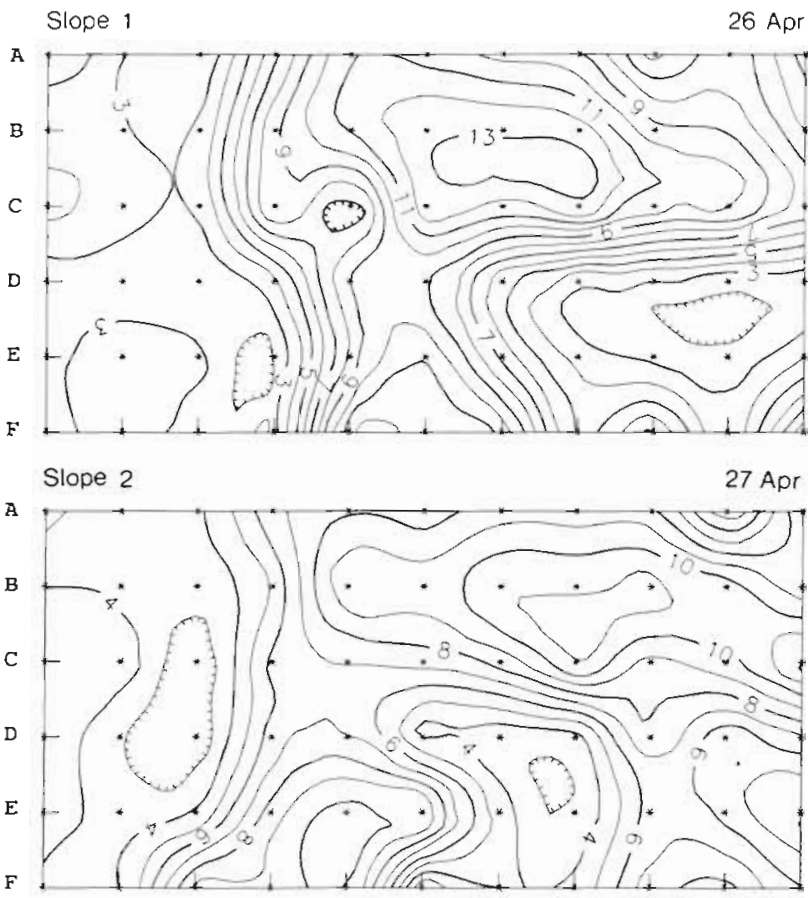

Slope 3

28 Apr

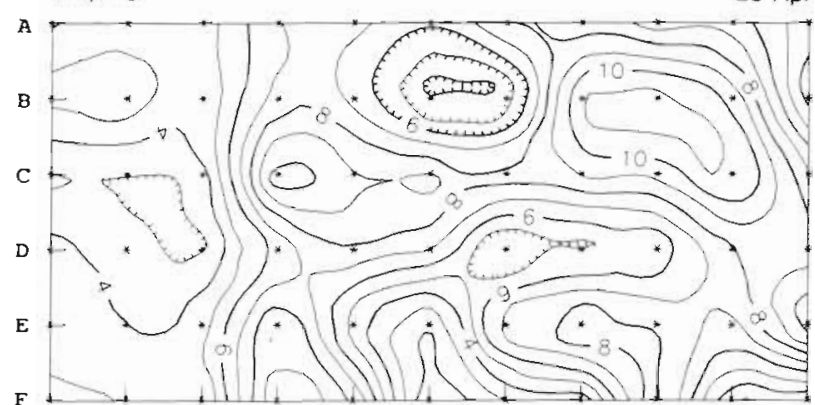

Slope 4

$30 \mathrm{Apr}$

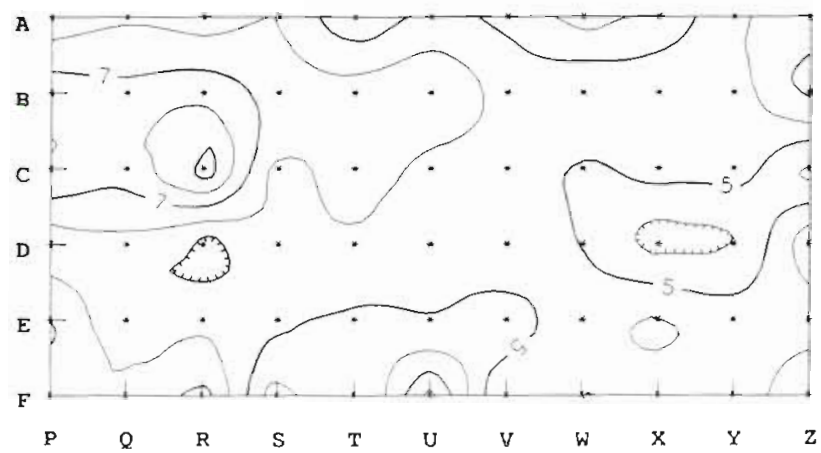

Fig. 6. Contour maps of the horizontal chlorophyll a distribution $\left(\mathrm{mg} \mathrm{m}^{-3}\right)$ in the 0 to $10 \mathrm{~m}$ water layer in the Slope grids 1 to 4

and increased smaller-scale variability. The primary production capacity values revealed patterns similar to the chlorophyll distributions, and were even more pronounced. Due to the lower spatial resolution these maps are not shown 

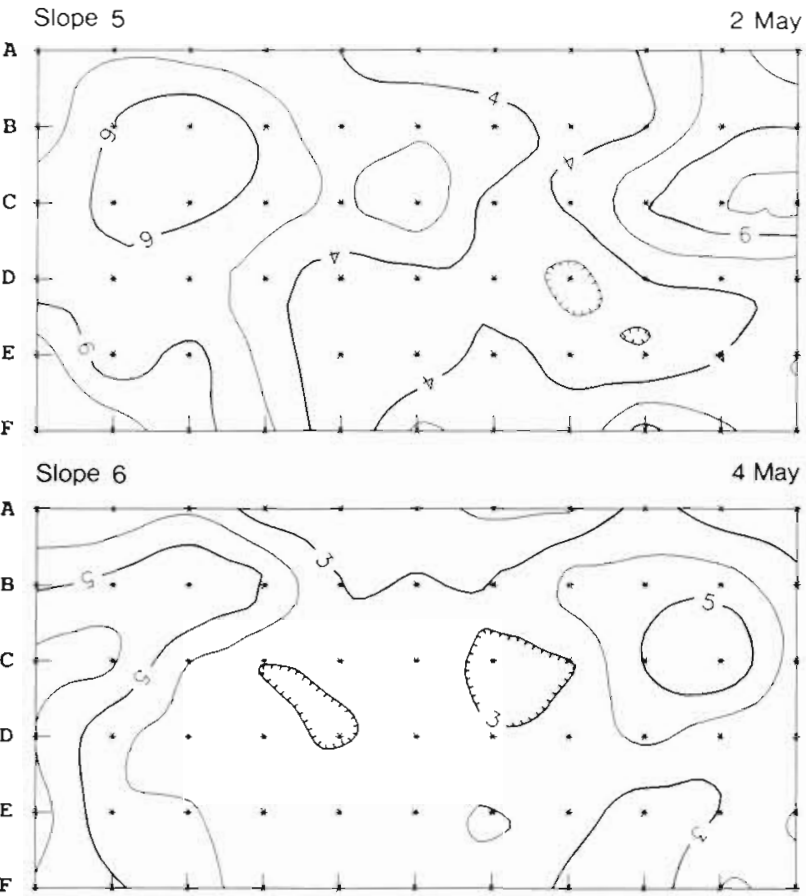

Slope 7
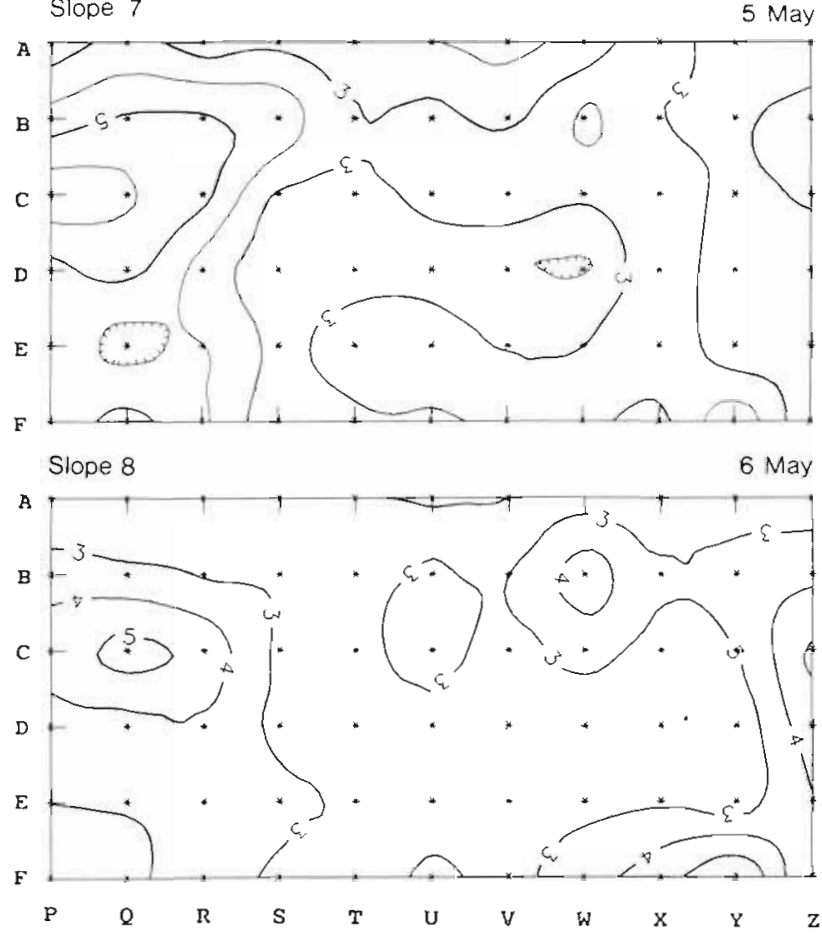

Fig. 7 Contour maps of the horizontal chlorophyll a distribution $\left(\mathrm{mg} \mathrm{m}^{-3}\right)$ in the 0 to $10 \mathrm{~m}$ water layer in the Slope grids 5 to 8

Since the development of the overall hydrographical pattern relative to the sampling frequency was slow, the time curves of different parameters can be followed separately in the synoptic-scale formations. The temporal development of the bloom followed an individual pattern in each formation, and none of the individual time-curves resembled the mean time-curve for the whole PEX area (Figs. 4 and 8 ). While sea-surface temperature showed an almost monotonous increase in all areas, smaller-scale spatial variability increased dramatically after the formation of the thermocline around 1 May, when the water temperature exceeded the temperature of maximum density (ca $2.4^{\circ} \mathrm{C}$ ). The relatively constant salinity values in each subarea confirm that the measurements in the individual structures are representative of the same water mass.

The first Eddy grid survey made on 25 April showed that the phytoplankton bloom in the adjacent mesoscale formations was in different developmental stages. While the bloom had reached its very high peak values in both eddies, the bloom in both lower- and highersalinity areas was still in the increasing phase with most of the chlorophyll and nutrient values already different from winter conditions. The vertical structure of the chlorophyll a concentration across both eddies is shown in Fig. 9. The water inside the cyclonic eddy core was homogeneous both horizontally and vertically (down to ca $40 \mathrm{~m}$ ). In the anticyclonic eddy, in comparison, the salinity stratification started at shallower depth (20 to $30 \mathrm{~m}$ ), and the high chlorophyll values were confined to a shallower surface layer. While both of the eddies supported very high chlorophyll levels near the surface, the total amount of chlorophyll $a$ in the water column was considerably higher in the cyclonic eddy $\left(>700 \mathrm{mg} \mathrm{m}^{-2}\right.$ ) due to the different vertical distribution.

In the upper layer of the both eddies the chlorophyll concentration started to decrease due to sedimentation before the formation of the seasonal thermocline and the depletion of inorganic nutrients (Fig. 8A). Inorganic nitrogen became rapidly depleted over the whole study area after the formation of the thermocline. In both the higher-salinity tongue and the lower-salinity western area, the bloom started to decline after the depletion of nutrients (Fig. 8B, C). The main difference was that the bloom in the shallow area reached the peak before the development of the thermocline, while the chlorophyll maximum in the higher-salinity tongue was attained after the thermocline was formed. The effects of smaller-scale phenomena (jet-currents, frontal upwellings etc.), visible on satellite images, on the development of the spring bloom were not resolved by the surveys on the Slope and Eddy grids.

\section{DISCUSSION}

The high-pressure area that dominated the weather system over the Baltic Sea during April-May 1986 was instrumental in creating low-wind conditions and only 

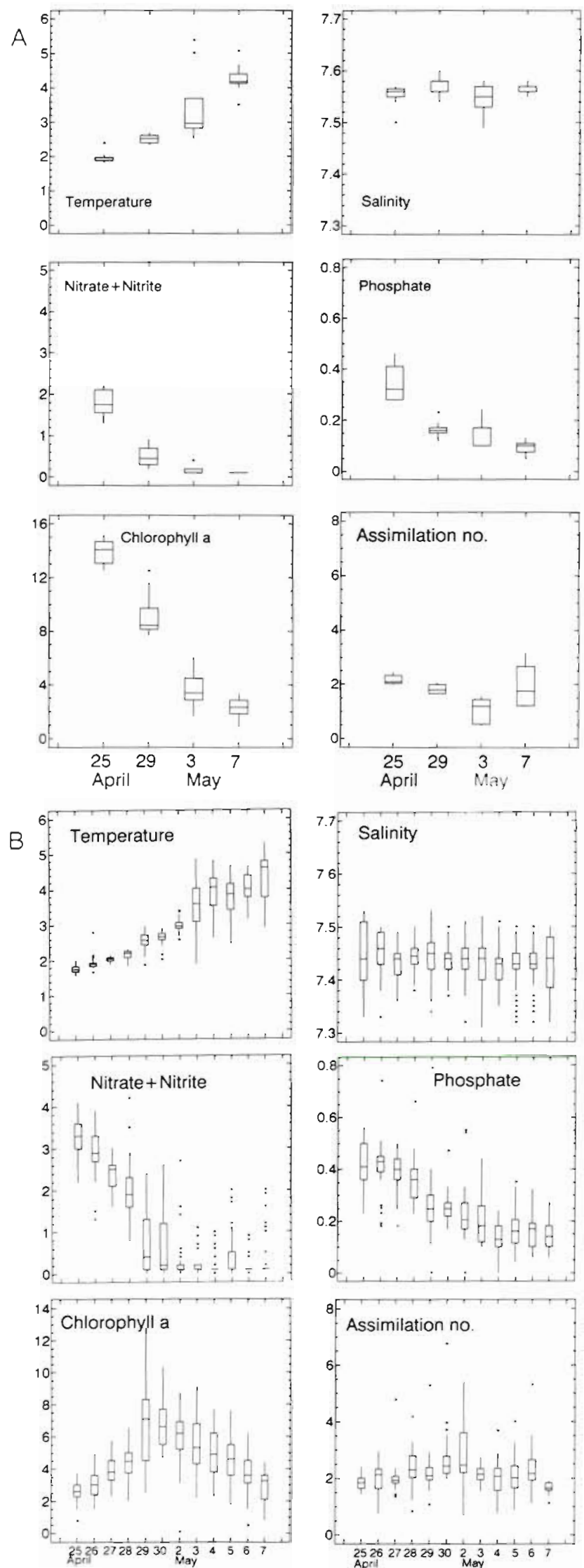

C
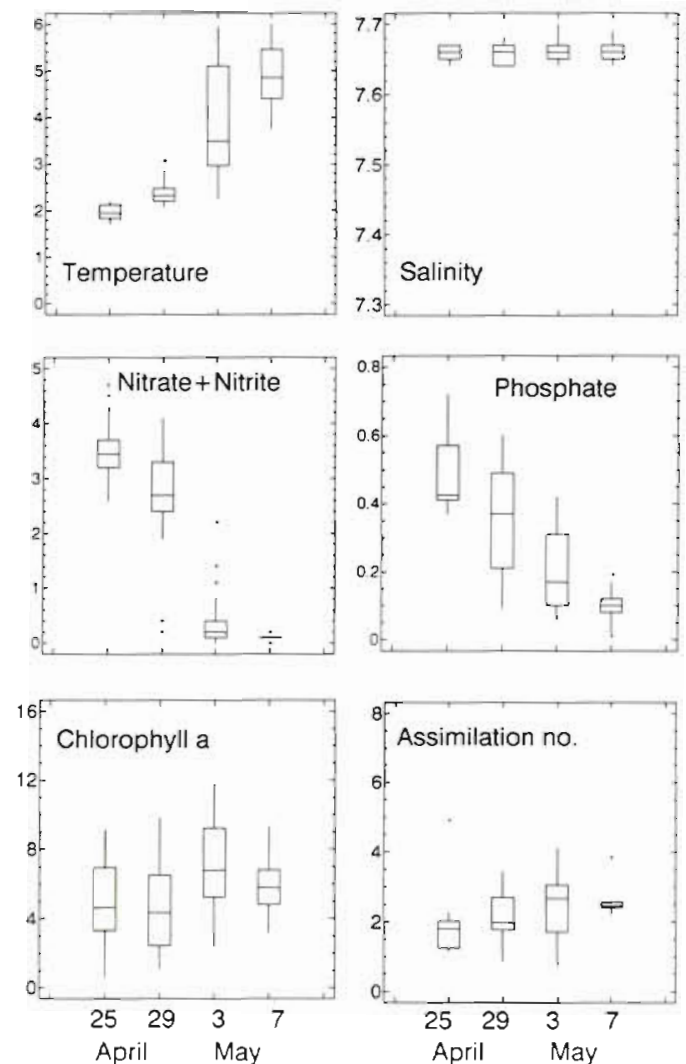

Fig. 8. Variability of temperature $\left({ }^{\circ} \mathrm{C}\right)$, salinity $(\% \circ)$, nitrate + nitrite $(\mathrm{mM})$, phosphate $(\mathrm{mM})$, chlorophyll a concentrations ( $\mathrm{mg} \mathrm{m}^{-3}$ ) and assimilation number (chl a/prim. prod. capacity) in the 0 to $10 \mathrm{~m}$ layer in (A) the cyclonic eddy, (B) the low salinity western area, and (C) the high salinity area. For a description of the graphical representation, see Fig. 3

brief moderate-wind events. This was probably the cause of the early bloom in 1986 compared to previous observations in the Gotland basin (Schulz 1985). The large-scale distribution of water masses in the area, e.g. the low-salinity water on the western shallow bank separated by a quasi-permanent front, is typical of the area (Elken et al. 1987).

The inherent salinity stratification of the Baltic Sea, which is due to its estuarine origin, plays a decisive role in the onset of the spring bloom. Apart from the main halocline, the vertical salinity profile usually contains less pronounced structures that are sufficient to restrict vertical mixing (Kahru \& Nômmann 1990). Such salinity stratification above the main halocline may be formed locally due to synoptic scale eddies, filaments etc., causing lateral advection and interleaving of water masses. This 'secondary' salinity stratification can be sufficient to suppress local vertical mixing (e.g. by thermal convection) when the water is still below the temperature of maximum density.

The seasonal thermocline in the Baltic Sea is established when the surface water temperature exceeds the 


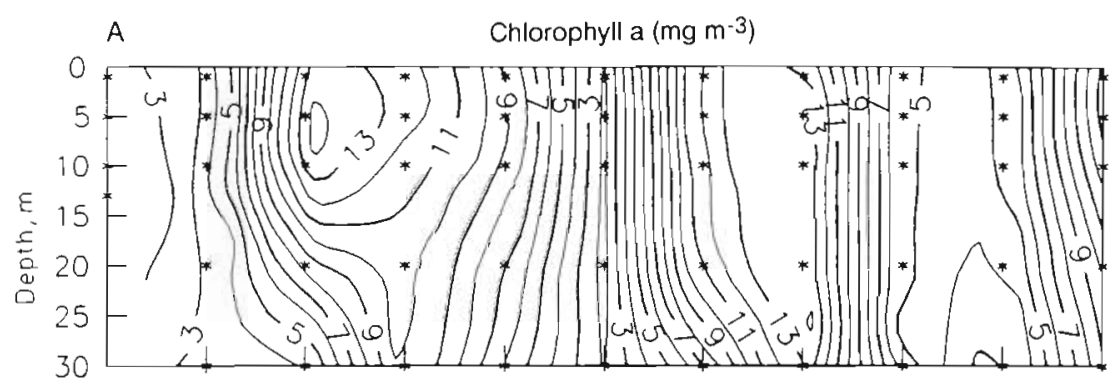

Fig. 9. Vertical distributions of (A) chlorophyll a $\left(\mathrm{mg} \mathrm{m}^{-3}\right)$ and (B) salinity (\%) along Line $C$ across the anticyclonic eddy ( 0 to $8 \mathrm{n}$ mile) and cyclonic eddy (14 to $24 \mathrm{n}$ mile) on 25 April. Salinity section, obtained with a towed vertically undulating probe, does not extend to the western shallow end of Line $C$ Salinity figure provided by M. Pajuste

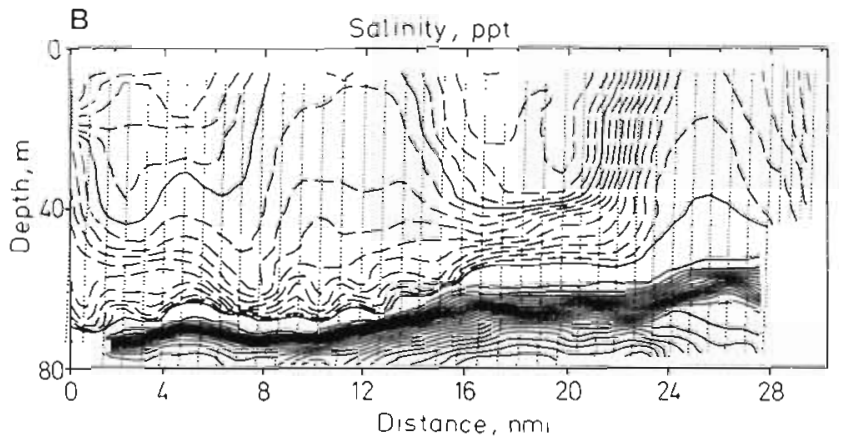

maximum density temperature (ca $2.4^{\circ} \mathrm{C}$ for the salinities in the Gotland basin). The formation of the thermocline may support an additional increase in the chlorophyll standing crop (e.g. the high-salinity tongue), or cause termination of the bloom by restricting the upward transport of nutrients (Bodungen et al. 1981, Lahdes \& Leppänen 1988, Kahru \& Nômmann 1990). Positive correlation between water temperature and chlorophyll concentration, frequently observed during the increasing phase of the spring bloom (e.g. Fig. 10), does not imply a causal relationship between temperature (or thermocline formation) and chlorophyll. Both the increase in temperature and that in chlorophyll concentration can be the result of locally restricted vertical mixing due to the salinity stratification. If the formation of thermal stability initiated the bloom development by limiting thermal convection, the relationship should clearly change shape at the maximum density temperature $\left(2.4^{\circ} \mathrm{C}\right)$. This, however, was not observed (Fig. 10).

Increased spatial chlorophyll variability during the spring bloom can be expected since the bloom marks a transition between different states of the pelagic ecosystem. The variability is more accentuated on the synoptic space scale because conditions for the commencement of the bloom are created locally by synoptic scale formations. The life histories of the bloom in each formation follow their own specific courses with their own particular plankton species assemblages and succession patterns. This was verified by the phytoplankton species data collected during PEX'86 (Kononen et al. unpubl.). Contrary to the luxurious uptake conception (Eppley 1981), the bloom started to decline

in the eddies before the exhaustion of inorganic nitrogen, most probably due to the self-shading effect.

It is widely accepted (e.g. Kaiser \& Schulz 1978) that the phytoplankton spring bloom starts earlier in shallow areas. However, the maximum chlorophyll concentration in the shallow western area was attained later than that in the eddies in the deeper central part. The chlorophyll concentration in the shallow western area never reached the maxima of the other areas, indicating different bloom dynamics.

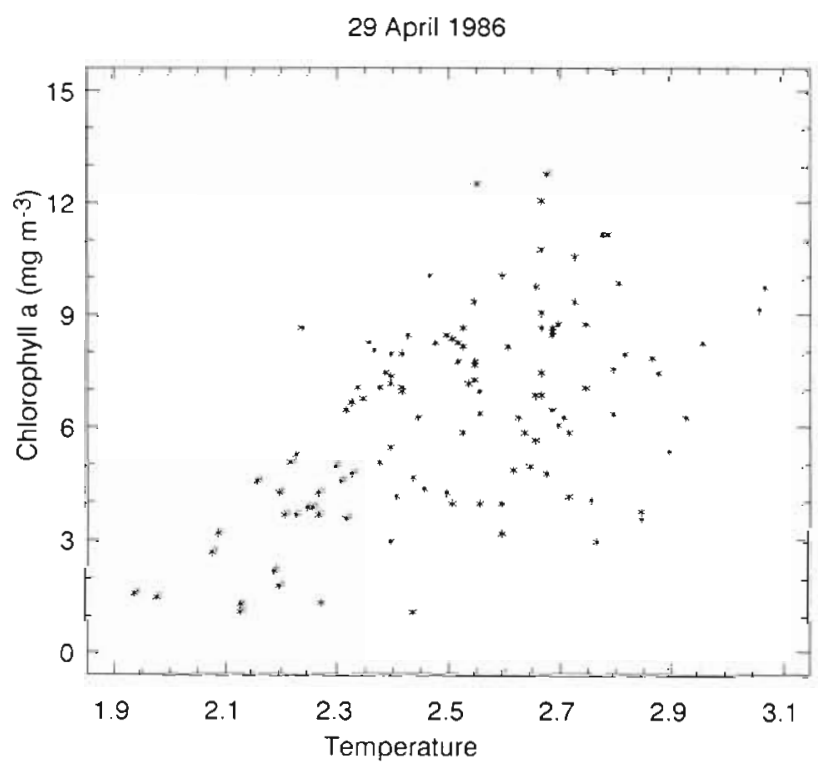

Fig. 10. Plot of chlorophyll a concentrations $\left(\mathrm{mg} \mathrm{m}^{-3}\right)$ as calculated from fluorescence versus temperature $\left({ }^{\circ} \mathrm{C}\right)$ at $5 \mathrm{~m}$ depth along Line $\mathrm{C}$ on 29 April 
Sedimentation explained the rapid decrease in phytoplankton concentrations in the eddies, with the sedimentation rate being species specific (Passow 1990). Mass sedimentation of the spring bloom is a well-known process in the Baltic Sea (e.g. Smetacek et al. 1984, Larsson et al. 1986, Leppänen 1988), but no conclusions can be drawn at this stage about the extent to which the sedimentation was triggered by external (such as nutrient or light limitation) or internal factors Low assimilation numbers indicated deterioration in the physiological condition of the phytoplankton during peak values in the eddies. To evaluate the difference in the peak chlorophyll a concentrations in relation to the nutrient reserves between the various areas, a rough calculation for the phytoplankton nutrient demand was made using a molar carbon to nitrogen ratio of 6.5 and a carbon to chlorophyll a ratio of 40 . The uptake of $3 \mathrm{mM}$ nitrogen in the shallow area during 25 to 30 April should produce ca $6 \mathrm{mg} \mathrm{m}^{-3}$ chlorophyll a. The increase of chlorophyll a in the water column at that time amounted to $\mathrm{ca} 5 \mathrm{mg} \mathrm{m}^{-3}$. To produce the peak chlorophyll a value of $14 \mathrm{mg} \mathrm{m}^{-3}$ found in the both eddies, ca $7 \mathrm{mM}$ nitrogen would be needed. Since the initial reserves were clearly smaller ( 4 to $5 \mathrm{mM}$ ), it seems probable that the extra nutrients were pumped into the euphotic zone by the eddies. The mechanisms for the introduction of nutrients into the upper layer and for maintaining such high levels of chlorophyll in the whole water column (>700 $\mathrm{mg} \mathrm{m}^{-2}$ ) are not clear. According to theoretical estimates (Lorenzen 1972), the maximum amount of chlorophyll $a$ that can be sustained in a water column is $333 \mathrm{mg} \mathrm{m}^{-2}$. As the values in the cyclonic eddy were more than double this limit, mechanisms not yet fully understood must have been involved.

Very high chlorophyll values such as those in the water column in the 2 eddies have not been previously reported in the Central Baltic Sea (cf. Schulz 1985). However, this does not mean that the bloom was exceptional because monthly measurements with a very coarse set of stations are not likely to reveal phenomena having temporal scales of a few weeks and spatial scales of around 20 to $30 \mathrm{~km}$. Chlorophyll concentrations $>20 \mathrm{mg} \mathrm{m}^{-3}$ have, however, been reported in the open Northern Baltic Proper during a frequently sampled spring bloom period (Leppänen \& Kononen 1988). High-resolution measurements made during the 1985 and 1986 spring bloom periods (Kahru \& Nômmann 1990) confirmed that the overall peak values were very similar in both years.

The vernal growth period holds a key position in determining the response of the Baltic Sea ecosystem to the observed increase in winter nutrient levels (Jansson et al. 1984). The structure and functioning of the pelagic food web during that phase determine how much nutrient from the initial reserves is transported out of the pelagic system by sedimentation, and how much is retained for recycling in the upper water layer. The spring bloom period should therefore receive more attention when evaluating trends in the trophic state of the sea. Due to the pronounced patchiness during this period, a high-resolution sampling strategy, different from conventional monitoring programmes (e.g. Helcom 1988), needs to be used.

\section{LITERATURE CITED}

Bodungen, B. v., Bröckel, K. v., Smetacek, V., Zeitzschel, B. (1981). Growth and sedimentation of the phytoplankton spring bloom in the Bornholm Sea (Baltic Sea). Kieler Meeresforsch. Sonderh. 5: 49-60

Dybern, B. I., Hansen, H.-P. (1989). Baltic Sea Patchiness Experiment - PEX'86 - Part 1: General Report. ICES Cooperative Research Report 163: 1-100

Elken, J., Talpsepp, L., Pavelson, J. (1987). Dynamics and distribution of water masses in the southern Gotland basin (polygon studies). Proceedings of the 15th Conference of the Baltic Oceanographers 1: 145-166

Eppley, R. W. (1981). Relations between nutrient assimilation and growth in phytoplankton with a brief review of estimates of growth in the ocean. In: Platt, T (ed.) Physiological bases of phytoplankton ecology. Can. Bull. Fish. Aquat Sci. 210: 251-263

Hällfors, G., Niemi, A. (1981). Vegetation and primary production. In: Voipio, A. (ed.) The Baltic Sea. Elsevier, Amsterdam, p. 220-237

Helcom (1983). Guidelines for the Baltic Monitoring Programme for the Second Stage. Baltic Sea Environment Proceedings 12: 1-251

Helcom (1988). Guidelines for the Baltic Monitoring Programme for the Third Stage. Baltic Sea Environment Proceedings $27 \mathrm{~A}: 1-49$

Horstmann, U. (1983). Distribution patterns of temperature and water colour in the Baltic Sea as recorded in satellite images: indicators of phytoplankton growth. Ber. Inst. MeeresKde Kiel 106:1-147

Horstmann, U, van der Piepen, H., Barrot, K. W. (1986). The influence of river water on the southeastern Baltic Sea as observed by Nimbus 7/CZCS imagery. Ambio 15: 286-289

Jansson, B.-O., Wilmot, W., Wulff, F. (1984). Coupling the subsystems - the Baltic Sea as a case study. In: Fasham, M. J. R. (ed.) Flows of energy and materials in marine ecosystems. Plenum, New York, p. 549-595

Kahru, M., Aitsam, A., Elken, J. (1982). Spatio-temporal dynamics of chlorophyll in the open Baltic Sea. J. Plankton Res. 4: 779-790

Kahru, M., Nômmann, S. (1990). Phytoplankton spring bloom in the Baltic Sea in 1985, 1986: Multitude of spatio-temporal scales. J. Cont. Shelf Res. 10: 329-354

Kaiser, W., Schulz, S. (1978). On the causes for the differences in space and time of the commencement of the phytoplankton bloom in the Baltic. Kieler Meeresforsch. Sonderh. 4: 161-170

Lahdes, E., Leppänen, J.-M. (1988). Cycling of organic matter during the vernal growth period in the open northern Baltic Proper. II. Nutrient development and chemical composition of organic matter. Finnish mar. Res. 255: 19-35

Larsson, U., Hobro, R., Wulff, F. (1986). Dynamics of the 
phytoplankton spring bloom in a coastal area of the northern Baltic Proper Contr. Askö Lab., Univ. Stock. 30: 1-32

Leppänen, J.-M. (1988). Cycling of organic matter during the vernal growth period in the open northern Baltic Proper VI. Sinking of particulate matter Finnish mar. Res. 255 $97-118$

Leppänen, J.-M., Kononen, K. (1988). Cycling of organic matter during the vernal growth period in the open northern Baltic Proper. III. Phytoplankton composition and estimation of loss rates of primary production. Finnish mar. Res. 255: $37-54$

Lorenzen, C. J. (1972). Extinction of light in the ocean by phytoplankton. J. Cons. int. Explor. Mer 2: 262-267

This article was submitted to the editor
Passow, U. (1990). Vertikalverteilung und Sedimentation von Phytoplanktonarten in der mittleren Ostsee während des Frühjahrs 1986. Ber. Inst. MeeresKde Kiel 192: 1-203

Schulz, S. (1985). Ergebnisse ökologischer Untersuchungen im pelagischen Ökosystem der Ostsee. Institut für Meereskunde, Rostock-Warnemünde

Smetacek, V., Bodungen, B. von, Knoppers, B., Peinert, R. Pollehne, F. Stegmann, P., Zeitzschel, B. (1984). Seasonal stages in characterizing the annual cycle of an inshore pelagic system. Rapp. P.-v. Réun. Cons. int. Explor. Mer 183: $126-135$

Steele, J. H. (ed.) (1978) Spatial pattern in plankton communities. Plenum Press, New York

Manuscript first received: December 12, 1989

Revised version accepted: June 12, 1990 